\title{
Job Opening for Nucleosome Mechanic: Flexibility Required
}

\author{
Mary Pitman ${ }^{1,2,+}$, Daniël P. Melters ${ }^{2,+}$ and Yamini Dalal ${ }^{2, *}$ (]) \\ 1 Department of Chemistry and Biochemistry, Institute for Physical Science and Technology, University of \\ Maryland, College Park, MD 20740, USA; mary.pitman@nih.gov \\ 2 Chromatin Structure and Epigenetic Mechanisms, Laboratory of Receptor Biology and Gene Expression, \\ Center for Cancer Research, NCI, NIH, Bethesda, MD 20892, USA; daniel.melters@nih.gov \\ * Correspondence: dalaly@mail.nih.gov \\ + These authors contributed equally.
}

Received: 11 February 2020; Accepted: 26 February 2020; Published: 1 March 2020

check for

\begin{abstract}
The nucleus has been studied for well over 100 years, and chromatin has been the intense focus of experiments for decades. In this review, we focus on an understudied aspect of chromatin biology, namely the chromatin fiber polymer's mechanical properties. In recent years, innovative work deploying interdisciplinary approaches including computational modeling, in vitro manipulations of purified and native chromatin have resulted in deep mechanistic insights into how the mechanics of chromatin might contribute to its function. The picture that emerges is one of a nucleus that is shaped as much by external forces pressing down upon it, as internal forces pushing outwards from the chromatin. These properties may have evolved to afford the cell a dynamic and reversible force-induced communication highway which allows rapid coordination between external cues and internal genomic function.
\end{abstract}

Keywords: chromatin; mechanics; nucleosomes; dynamics; epigenetics

\section{Introduction}

Chromosomes are complex nucleoprotein polymers, which contain a treasure trove of genetic and epigenetic data which is folded in the constrained space of the nucleus. The chromatin polymer permits spatiotemporal regulation to correctly access, repress, replicate, repair, and segregate the genome. Transcription of the genome is highly sensitive to external cues and stimuli, often bursting on a seconds time scale [1,2]. The base-unit of chromatin is the nucleosome, a core of eight histone proteins that wrap $147 \mathrm{bp}$ of DNA, which forms a bead-on-a-string nucleosome array. Therefore, understanding the material properties of nucleosomes, and how such properties can be modulated, is an exciting new avenue in chromosome biology. At the nanoscale, macromolecular structures rely on elasticity, viscosity, and thermal motion for mechanical force development $[3,4]$. For example, chromosome movement during mitosis is dictated by frictional resistance [5-8]. These characteristics arise when the Reynolds number, which quantifies the relative importance of friction and inertia, is very low [9]. Thus, only when forces are generated, will there be action. The moment force production ceases, the action stops. Consequently, for a molecular motor to function, force generation is necessary. For instance, a wave-ratchet-wave model would allow for repeated force generation. Indeed, one mode by which chromatin remodelers are thought to function-in an ATP-dependent manner-is such a mechanism [10].

Physical properties of macromolecules that influence the amount of friction, such as elasticity, dictate how these macromolecules interact with each other. Structural proteins frequently have elastic mechanical properties [11] providing both strength and extensibility, together with low resilience, 
giving them notable resistance to fracture. Extreme examples are mammalian tendons and spider dragline silk $[12,13]$. Elasticity is formally defined by Hooke's law, which states that the strain in a material is proportional to the applied stress within the elastic limit, which is quantified by Young's modulus. Elastic properties of macromolecules are encoded by their quaternary and higher order structures, as either structurally disordered networks of flexible fibers, or structurally ordered macromolecules [14,15]. Chromatin fibers are in the regime of elastomers found elsewhere in nature, yet little is understood about how equivalent mechanical properties might contribute to its function. Deciphering how mechanical inputs alter the chromatin fiber, and conversely, how chromatin communicates cues back to the nuclear membrane, are relatively underexplored topics in biology. In this review, we highlight recent work on the material properties and dynamics of chromatin, and discuss how such properties might translate to chromatin fiber function in healthy states, which may be abrogated in the diseased state.

\section{Nanoscale Dissections of Chromatin Mechanobiology}

The elastic nature of chromosomes was first observed decades ago when the elastic recoil of chromatin was visualized by micro-manipulation experiments [16]. Indeed, the earliest documented quantitative micromanipulation experiments on intact cells were performed by Ethel Glancy D'Angelo in 1946 [17], when she reported that chromosomes from various Chironomus species can be elastically stretched to five times their original length without hysteresis $[17,18]$. A decade later, Bruce Nicklas used microneedle experiments coupled with radiation-induced damage of grasshopper chromosomes and reported similar results [19]. These early studies were made possible by increased spatial resolution of micromanipulators, and clearly demonstrated that the chromatin polymer had mechanical properties beyond that expected from simple folding of a linear chain.

New technological and theoretical developments continue to move questions of biological importance within reach. The development of micro-magnetic-tweezers, capable of manipulating chromatin on the nanometer scale, made it possible to measure the elasticity of biological molecules. A hierarchical decrease in Young's modulus is observed for chromatin factors, where DNA is much more rigid compared to nucleosomes, which in turn are more rigid than chromosomes, whereas the nucleus has the lowest Young's modulus (Table 1). It is important to keep in mind, however, that when discussing the material properties of biological mediums, context matters. Biological parameters such as charge, temperature, pressure, and cellular microenvironment can alter reported material properties.

Table 1. The Young's modulus across single molecules and macromolecules differ by orders of magnitude.

\begin{tabular}{ccc}
\hline Substrate & Young's Modulus & References \\
\hline DNA & $0.3-1 \mathrm{GPa}$ & {$[20]$} \\
Protein & $0.02-0.8 \mathrm{GPa}$ & {$[21-29]$} \\
Nucleosome & $2.8-15.4 \mathrm{MPa}$ & {$[15]$} \\
Chromosome & $40-400 \mathrm{~Pa}$ & {$[30,31]$} \\
Nucleus & $250 \mathrm{~Pa}$ & {$[32]$} \\
\hline
\end{tabular}

\section{Mechanical Signal Transduction into the Nucleus}

The elastic properties of chromatin and the nuclear environment play a direct role in signal transduction by mechanical force, that is, mechano-transduction [33-36]. While the primary dogma in biochemistry is signal transduction through chemical pathways, mechanical signal transduction may be equally important with the benefit of a direct and rapid response. For example, while activation of the Src kinase by epidermal growth factor occurs over tens of seconds, mechano-transduction by integrins occurs in less than $0.3 \mathrm{~s}$ [33]. The nucleus is subjected to a variety of different mechanical forces, such as stretching, pushing, compression, tension, and shear stress [37], making it likely that the 
cell has evolved mechanisms to employ these signals to execute rapid, possibly transient, changes in gene expression programs.

The biochemical response to a mechanical signal for chromatin condensation and gene expression [38,39] has recently been explored by various labs as a rheostat of chromatin regulation [34-37,40-43]. Mechanical signaling also plays a vital role within the nucleus during cell division. For the faithful segregation of mitotic chromosomes, the spindle assembly checkpoint is regulated by pushing and pulling forces generated during mitosis. When a critical tension is reached, anaphase proceeds [8]. In this review we focus primarily on mechanical transactions that occur upon the chromatin fiber in the interphase stage of the cell cycle.

\subsection{Mechanical Communication between the Cytoskeleton and Chromatin}

The interphase nucleus receives mechanical inputs from inside and outside the cell via the cytoskeleton. For example, nuclear migration and nuclear positioning are critical during organismal developmental [44-46] and are coordinated by microtubules and actin dynamics (Figure 1). The cytoskeleton is connected to the nucleus via the linker of nucleoskeleton and cytoskeleton (LINC) complexes, which link the nucleoskeleton to the cytoskeleton, through a network of SUN and KASH domain containing proteins. The SUN domain spans the inner nuclear membrane, creating the physical connection with the nuclear lamina network, whereas the KASH domain spans the outer nuclear membrane. Different KASH domain proteins interact with either actin, intermediate filament, or microtubules. Interestingly, the length of the KASH domain corresponds to the amount of force that can be transferred [47]. Altering the length of the KASH domains resulted in defective nuclear migration and nuclear anchorage in the nematode C. elegans. This nucleoskeletal tethering has been found to be a common feature, especially for meiotic chromosomes [44,45,48].

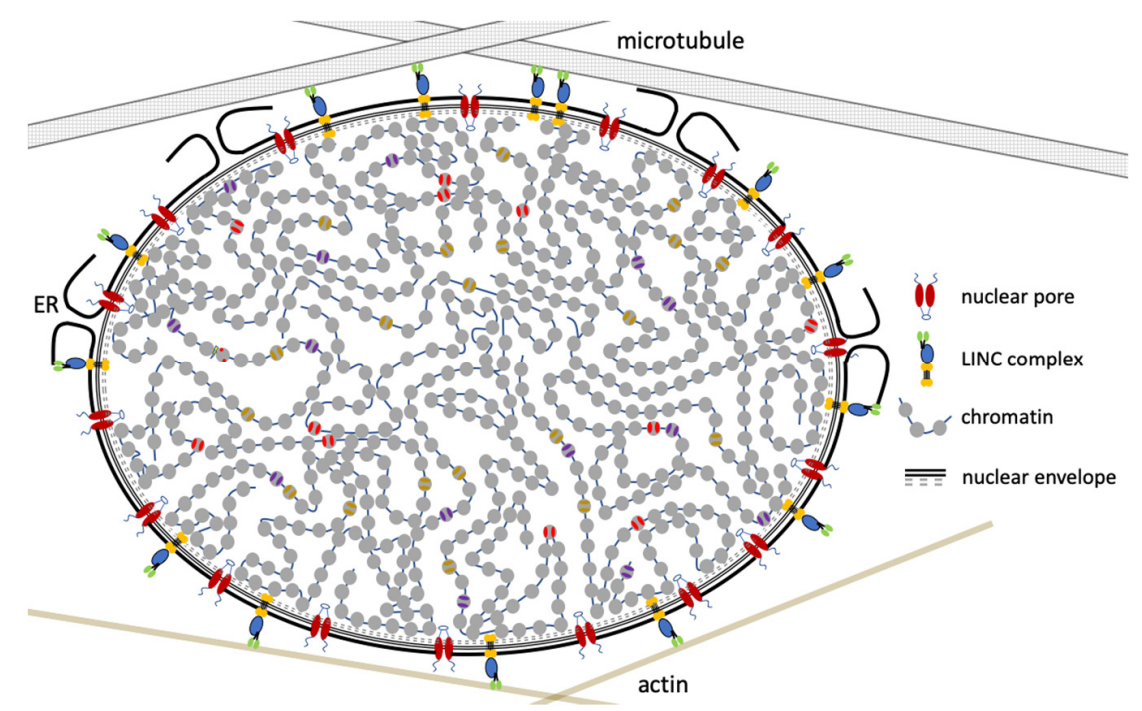

Figure 1. The nucleus is an integral part of the cell's cytoplasm. The cytoskeleton interacts with chromatin through the linker of nucleoskeleton and cytoskeleton (LINC) complex, allowing mechanotransduction of signals from outside the cell to swiftly and directly impact chromatin structure and gene expression.

In interphase cells, mechano-transduction mediated by cytoskeleton-tethering alters gene expression. For example, mechanical to chemical signal propagation in chromatin was shown to occur in a recent study in which magnetic beads were attached to the cellular surface to apply a controlled external force [38]. In another demonstration of mechano-transduction, chromatin deformation, and force-induced transcription of GFP tagged dihydrofolate reductase transgene was observed [38]. A third example is where the mobilization of local chromatin sites through a complex of transcription 
factors and myosin, utilizing the nuclear-actin matrix and heat shock protein Hsp90, resulted in the enrichment of the local chromatin with H2A.Z nucleosomes [49].

By measuring the root mean square fluctuations of the nuclear envelope in real time, Schreiner and colleagues found that untethered chromatin resulted in highly deformable nuclei [50]. Indeed, the integrity of the nuclear envelope is important to maintain nuclear stability under these forces [51]. Thus, it appears that a physical link between the cytoskeleton and chromatin provides a means by which the cell can protect and regulate the nucleus in a spatiotemporal manner.

\subsection{Chromatin Deformation in Response to Cell Motility}

Cell migration is commonly found in organisms, for example, lymphocytes, macrophages, and metastatic cancer cells all migrate. Such cells squeeze through very small spaces, forcing the cellular interior to drastically deform (Figure 2). One mechanism that these cells deploy during this process is to condense their chromatin $[34,36]$. These kinds of chromatin distortions are fascinating to consider because they occur, presumably reversibly, on a relatively fast time scale. It is not yet known whether during these motility-induced chromatin conformational changes, transcribed chromatin is more susceptible to DNA damage or faulty DNA repair under force, and whether condensed chromatin associated with the nuclear lamina adopts a state which is protective. One could hypothesize that heterochromatin, which has increased local contacts with the nuclear periphery, may have a better buffering capacity to dissipate shearing forces. Indeed, evidence supports this notion, because DNA damage commonly correlates with local decondensed or relaxed chromatin [52,53], although some heterochromatin domains do not decondense upon DNA damage [54]. Concurrently, it will be fascinating to study how species which lack heterochromatin factors [55] adapt to shearing forces.
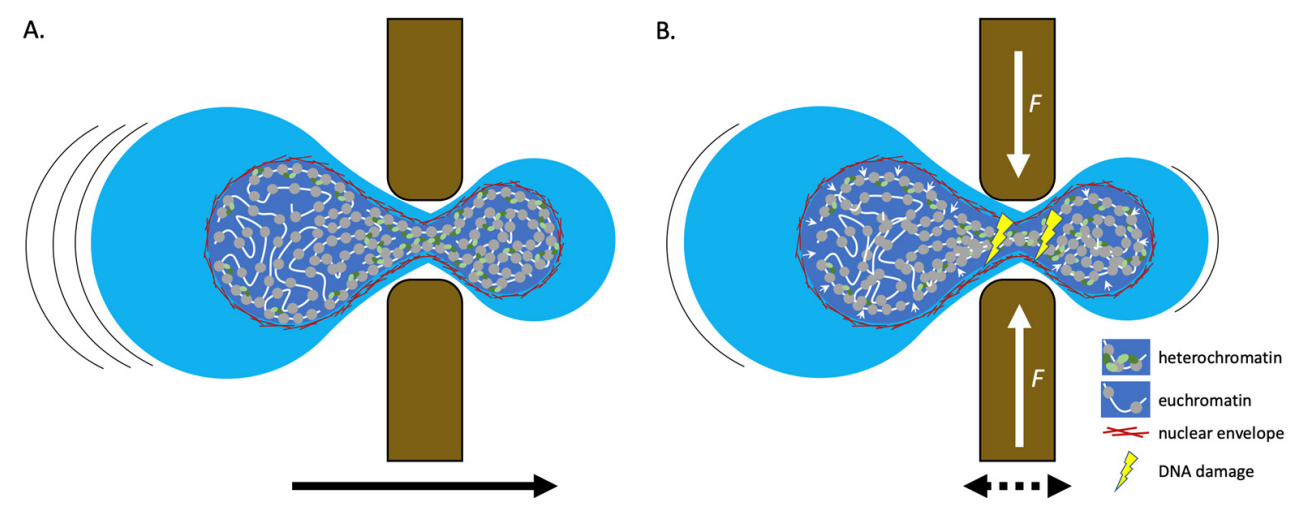

Figure 2. Chromatin dynamics during migration. (A) When a cell migrates (black arrows) through a small space, resulting in extensive compression of the cellular interior, chromatin tends to become hyper condensed. As we predict that heterochromatin is more gel-like than euchromatin, this might facilitate the nucleus to move through the gap faster, in a capillary suction-like manner. (B) When a cell is exposed to extensive compression forces (white arrows) or is stuck in a gap, the chromatin will eventually detach from the nuclear envelope and becomes more susceptible to DNA damage. This supports a model where chromatin-nuclear envelope contact serves to protect the DNA in a multi-contact manner. Intriguingly, dual functions for DNA repair factors have been observed. In addition to facilitating DNA repair, some DNA-repair factors have non-DNA repair functions. ATR that is localized to the nuclear periphery relocates upon osmotic stress and mechanical stretching, regulating chromatin condensation and nuclear envelope breakdown [56-58]. A deep mechanistic dissection of how DNA damage is repaired under force regimens will be extremely important, as well as how the DNA repair machinery manages mechanical forces.

Mechanical loading of chromatin as a consequence of cell migration is dependent on the actin cytoskeleton and LINC complexes [59,60] (Figure 3A). Cytoskeletal contraction induces release of ATP and $\mathrm{Ca}^{2+}$, mediating the import of methyltransferases and histone deacetylates, both silencing 
and activating gene expression $[34,35,40]$. Nevertheless, how chromatin stretching precisely activates a specific genetic program remains unclear. Indeed, prolonged force application has been shown to result in decoupling of heterochromatin from the nuclear lamina, which results in extensive transcriptional silencing [61].

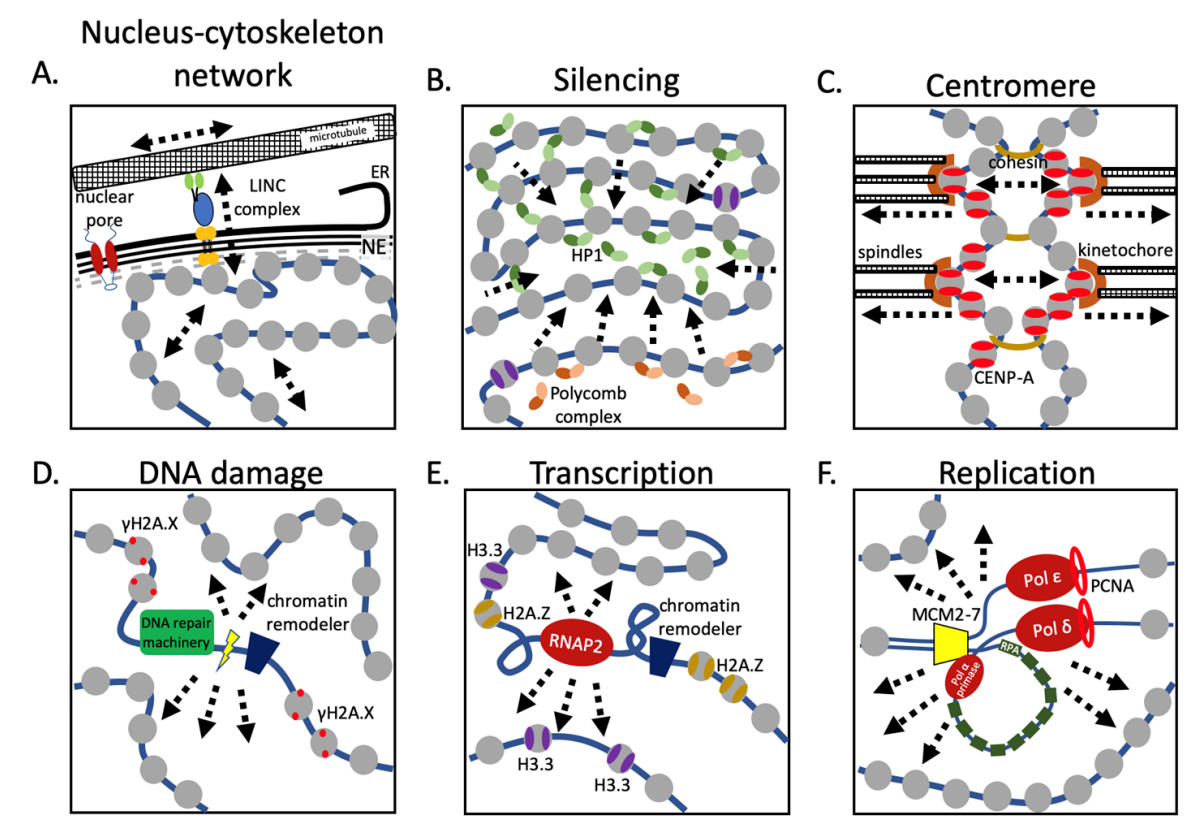

Figure 3. Nuclear machinery alter chromatin properties. (A) Physical forces are transmitted to the chromatin through a trans-nuclear envelope protein complex, altering both chromatin compaction and gene transcription. (B) Gene repression is commonly achieved through heterochromatin formation by either HP1 or Polycomb complexes, resulting in chromatin condensation and reduced chromatin elasticity. (C) Mitosis is a highly physical event, where in a highly coordinated manner, chromosomes are moved over extensive distances through the mitotic spindle machinery. The pushing and pulling forces that are excepted on the chromosomes, and especially the centromeric chromatin, are critical in satisfying the spindle checkpoint. (D) DNA damage must be repaired as quickly as possible, recruiting the DNA repair machinery, and locally decondensing chromatin, temporarily altering the local chromatin dynamics in part by enrichment of phosphorylated H2A.X nucleosomes. (E) Gene transcription is one of the most profound events in the nucleus, where the transcriptional machinery distorts the DNA double helix both behind and in front of the RNA polymerase. Highly transcribed regions are also enriched for H2A.Z and H3.3 nucleosomes. These nucleosomes might alter the local chromatin properties, potentially bringing together distant sites, such as enhancers and promoters. (F) Replicating chromatin has to decondense for the replication machinery to pass through, while at the same time maintaining distinct chromatin marks to be present on both newly formed strands. This highly dynamic and local event might temporarily increase the chromatin's elasticity. ER = endoplasmic reticulum, NE = nuclear envelope.

Based on these studies, an intriguing idea emerges that the chromatin fiber may function as a time-dependent, mechanosensitive rheostat. Subtle fluctuations in time and force scales can result in different outcomes at discrete locations on the fiber.

\section{Mechanobiology of the Chromatin Fiber Across Scales}

Only a fraction of the total chromatin is in direct contact with the nuclear periphery; indeed, the bulk of chromatin is located in the nucleoplasm. The shear abundance of nucleosomes and other nuclear proteins make them difficult to study at the single molecule resolution, in vivo. Major questions that have dominated the field for decades are whether the genome is organized in the nucleus, and whether such organization reflects function [37]. The development of chromosome conformation 
capture (Figure 3C) [62] sparked a massive push in the development of both proximity-ligation sequencing technologies and computational models to analyze and interpret the experimentally produced data $[63,64]$. How the three-dimensional organization of the genome, as well as distinct loci inform us about functional interaction is subject to intense studies. As discussed in detail below, to answer these fundamental questions, a synergistic confluence of in silico computational modeling and experimental biological approaches have been developed [62,65-67].

\subsection{Computational Advances in Mechanobiology of Chromatin and Nucleosomes}

To analyze and comprehend experimental data (reviewed in [68]), such as Hi-C, novel biophysical models were developed in an attempt to reconstruct chromosome topology and folding [34-36]. Statistical mechanics based chromatin models trained on Hi-C contact maps have also been developed, inspired by maximum entropy approaches previously applied to the protein folding problem $[69,70]$. Notable pioneering efforts resulted in applying an energy landscape model to extract the equilibrium ensemble of chromatin conformations known as the minimal chromatin model [71]. Interestingly, this minimal chromatin model shows a bias for open chromatin to localized at the edge of chromosome territories and phase separation between chromatin types. In addition, experimental data is also vital as a comparison for bottom-up approaches where a physical model is derived and then the output is checked for accuracy. One example of a recent top-down model [72] implemented the physics of block co-polymers and recapitulated Drosophila Hi-C data. Their tool, IC-Finder, predicts how 3D chromatin folding influences gene regulation. Such algorithms could also conceivably be developed for mechanical studies where chromatin topology is altered in response to force. DNA geometry and electrostatic interactions between nucleosomes can also inform chromatin models through twist angles between consecutive nucleosomes [73-75] or through steric studies that assume maximally compact face-to-face packing of the nucleosomes [76,77]. However, other approaches have historically leveraged the elasticity of chromatin for their predictive power. These methods can involve Brownian dynamics or Monte Carlo simulations [73]. Work was also done to model how nanoscale physical and geometric changes perturb the structure of chromatin at the mesoscale level and found that DNA elasticity, local geometry and linker DNA length play a key role in the topology of genome packaging [78].

Another major advantage of all-atom molecular dynamics (MD) simulations, is the capacity to observe minute fluctuation across an entire nucleosome, something single-molecule experiments cannot. Comparing the canonical H3 nucleosome to the centromere-specific CENP-A nucleosome showed that CENP-A nucleosomes display greater internal motions, in part because of the shearing motion at the four-helix bundle [79]. These results were extended by the recently developed minimal cylinder analysis (MCA) [80], which allows the Young's modulus to be derived from all-atom MD simulations. One logical prediction of a macromolecule with greater intrinsic internal motions is that they are more elastic (lower Young's modulus) than their canonical counterpart. Indeed, this is what was observed [15]. Interestingly, MCA showed that the heterotypic CENP-A:H3.3 nucleosome, which has been observed in cancer cells [81,82], had a Young's modulus in between CENP-A and H3 nucleosomes [80]. Furthermore, the CENP-A binding protein CENP-C suppressed the internal motions, resulting in a higher Young's modulus [15]. In addition to histone variants, the linker histone H1 family [83] impact the chromatin fiber dynamics, most notably by inducing chromatin condensation [84]. A recent course-gain mesoscale modeling study showed that different $\mathrm{H} 1$ variants differently alter the fiber structure, sedimentation rate, packing ratios, and bending propensities [85]. These data argue for a link between mechanical properties of nucleosomes and chromatosomes (nucleosomes $+\mathrm{H} 1$ ) and epigenetic control.

Another epigenetic layer are the post-translational modifications (PTMs) of nucleosomes, which have been found to alter nucleosome dynamics in silico. For instance, charge altering PTMs may increase transcription, nucleosome accessibility, and that additive effects of PTMs might be nonlinear [86]. MD simulations showed that acetylation of the core histone residue (K122 in $\mathrm{H} 3$ and K124 in CENP-A) rigidifies the nucleosomes in such a way that kinetochore seeding is 
blocked [87-90]. Intriguingly, MD simulations predicted the acetylation of K124 of the CENP-A nucleosomes to negatively affect CENP-C binding. Indeed, in vivo experiments confirmed these computational predictions [87].

Cumulatively, advances in computational modeling have incorporated biophysical principles to advance our understanding of how a long nucleoprotein polymer behaves. With cutting edge biophysical tools that can be applied in vitro and in vivo, these theoretical frameworks and resulting predictions can be rigorously tested by experimentation.

\subsection{Experimental Advances in Mechanobiology of Chromatin and Nucleosomes}

Although most of the nucleosomes found in the nucleus are canonical H3 nucleosomes, nucleosomes containing histone variants and PTMs tend to accumulate at certain sites, such as actively transcribing enhancers, promoters (Figure 3E), genes, sites of DNA damage (Figure 3D), centromeres (Figure 3C), and telomeres. This raises the question: How do pioneer and transcription factors find their sites of activity fast and efficiently in a sea of apparently uniform chromatin [91]? Do active sites stand out from the rest of the genome? One possibility that has been explored in recent years is that modified nucleosomal patches [92-94] create a unique local chromatin environment, simply by having distinct material properties that cause them to extrude locally from the rest of the genome. A simple analogy is to alter a stitch when knitting, which generates an identifiable pattern that pops out from the background. Taking this one step further, a "like-attracts-like" origami folding model can be envisioned, in which the three-dimensional folding of the genome contributes to the affinity between distant loci as a consequence of their chromatin fiber's innate similar material or topological properties.

Examples of the extrusion idea, whether by mechanical features, or phase transitions, exist in the literature [15,80,95-97]. First, a recent cryoEM study of tri-nucleosomes showed that a single CENP-A nucleosome flanked by two $\mathrm{H} 3$ nucleosomes created an untwisted structure, demonstrating the power of a single nucleosome to alter the "stitch" of the fiber [95]. A second example comes from a recent study (from our lab), which dissected nucleosomal elasticity for the first time using both computational approaches and nanoindentation AFM studies. We reported that CENP-A nucleosomes are twice as elastic as canonical $\mathrm{H} 3$ nucleosomes, but that kinetochore protein binding suppressed the elastic state. Indeed, in vivo, a domain of more elastic CENP-A nucleosomes, in a bed of otherwise rigidified kinetochore bound CENP-A was postulated to extrude small stretches of elastic chromatin fiber, upon which the local recruitment of transcription machinery depended [15,80]. A third example is that of fission yeast heterochromatin protein Swi6, which binds to H3K9me3 nucleosomes, and subsequently compacts and transcriptionally represses the chromatin fiber (Figure 3B). Interestingly, this interaction also induces increased nucleosome core accessibility as measured by HDX-MS and NMR [96]. Using in vitro system, using an optical trap, both modified mononucleosomes and mononucleosomes containing a histone variant altered the time it took an RNA polymerase 2 to unwrap DNA from a nucleosome [97].

In vitro mononucleosome studies have provided invaluable insights into how nucleosomes behave. Yet, in the cell, nucleosomes exist exclusively as part of a chromatin fiber in the context of a very crowded nucleus. Indeed, live cell imaging combined with computational modeling showed that RNA polymerase 2 constrains the motions of single nucleosomes [98]. Similarly, nucleosomes in the context of heterochromatin are also less dynamic [99] (Figure 3B). Indeed, a recent computational study suggested a role for nucleosomes in the kinetic proofreading of activator-promoter recognition [100], tantalizingly pointing towards a model where mechanobiological features of individual nucleosomes drive enhancer-promoter interactions. Therefore, it is of immediate interest to understand how changes in nucleosome distortions will impact the nucleosome's capacity to be modified by chromatin remodelers, whether they will promote or inhibit RNA polymerase processivity, and whether this changes the 3D spatial configuration of the chromatin fiber. In addition to mitosis (Figure 3C), replication also induces dramatic changes to the chromatin fiber (Figure 3F). How these changes alter 
the surrounding chromatin or the capacity of the cell to adequately respond to mechanical forces remains unexplored.

\section{Future Perspectives: Mechanobiology of Chromatin in Disease}

Changes in cell mechanics are associated with pathologies such as osteoarthritis, asthma, cancer, inflammation, and malaria [101,102]. Mechanobiological properties of the chromatin fiber are highly dependent on the molecular composition of the chromatin, most notably histone variants, PTMs, and chromatin binding factors. One of the most dramatic events a chromatin fiber can experience is a double strand break. Indeed, in cancer cells, higher levels of dsDNA breaks are commonly observed [103]. During the DNA damage response, chromatin commonly decondenses [52,53]. This feature of chromatin decondensation is not unique to the DNA damage response. In prostate cancer for instance, chromatin is markedly relaxed [104]. This is in part driven by SWI/SNF recruitment to heterochromatin, resulting in eviction of the polycomb complex in an ATP-dependent manner [105]. By evicting polycomb complexes, a more general open chromatin state is created. It is conceivable that subsequently histone variant nucleosomes are aberrantly accumulated on the chromatin fiber, changing the mechanobiological properties of the genome. Indeed, aberrant accumulation of histone variant nucleosomes has been observed for the centromeric CENP-A nucleosomes [81,82,106], including at cancer-associated translocation hotspots [82]. The importance of tight regulation of deposition of histone variant nucleosomes is highlighted in Floating-Harbor syndrome, where one of the two copies of the H2A.Z genes, which differs by three residues, is misincorporated, resulting in a distinctive craniofacial development [107]. Indeed, developmental incorporation of H2A.Z can differ between two closely related species [108], highlighting how precise spatiotemporal incorporation of distinct nucleosomes can be critical. It has to be noted that incorporation of H2A.Z nucleosomes requires chromatin remodelers, which are also a key component along with variants of the linker histone, in generating nucleosome repeat lengths $[109,110]$. Chromatin remodelers are frequently mutated in cancers [111]. How these mutants alter the mechanical properties of the chromatin fiber is an unexplored question. In addition, histone genes are frequently mutated in cancer [112,113]. One striking example is the H3K27M mutation which is found in about $80 \%$ of pediatric diffuse intrinsic pontine gliomas [114-116]. This mutation inhibits PRC2 activity, resulting in global reduction in H3K27me3 levels and increased proliferation $[117,118]$. How a single mutated allele among the many copies of histone genes can contribute to disease is only now beginning to be understood. Nevertheless, the paradigm that emerges from the sum of these data, is that tiny changes to the chromatin fiber can have significant clinical outcomes, whether by misincorporation, mislocalization, or attenuated remodeling. A recent in vitro study showed that the incorporation of H2A.Z nucleosomes at a nucleosome free region by the SWR chromatin remodeler is temperature sensitive [119], adding yet another layer to how a physical property can subtly alter the epigenetic landscape. Altogether, we speculate that seemingly nanoscale changes alter the mechanical properties of chromatin in a context-dependent manner. Completely lacking from the current debate is also the evolutionary context in which these properties evolved. It will be of great interest to study whether mechanical properties or mechanotransduction pathways of chromatin are conserved, or diverge across the species, and whether such adaptive strategies co-evolved with discrete biological outcomes. These currently relatively understudied themes in chromatin biology present exciting future pathways for theoretical and experimental dissection using a broad array of cutting-edge technologies.

Funding: This research was funded by the joint NCI-UMD Cancer Technology Partnership (MP) and the Intramural Research Program of the National Institutes of Health (DPM and YD).

Acknowledgments: We thank Minh Bui for critical reading of the manuscript.

Conflicts of Interest: The authors declare no conflict of interest. 


\section{References}

1. Kolesov, G.; Wunderlich, Z.; Laikova, O.N.; Gelfand, M.S.; Mirny, L.A. How gene order is influenced by the biophysics of transcription regulation. Proc. Natl. Acad. Sci. USA 2007, 104, 13948-13953. [CrossRef] [PubMed]

2. Lenstra, T.L.; Rodriguez, J.; Chen, H.; Larson, D.R. Transcription dynamics in living cells. Annu. Rev. Biophys. 2016, 45, 25-47. [CrossRef]

3. Niwayama, R.; Shinohara, K.; Kimura, A. Hydrodynamic property of the cytoplasm is sufficient to mediate cytoplasmic streaming in the Caenorhabiditis elegans embryo. Proc. Natl. Acad. Sci. USA 2011, 108, 11900-11905. [CrossRef] [PubMed]

4. Boal, D. Mechanics of the Cell, 2nd ed.; Cambridge University Press: Cambridge, UK, 2012.

5. Hughes, A.F. Anaphase movements in the living cell: A study with phase contrast and polarized light on chick tissue cultures. J. Exp. Biol. 1948, 25, 45-72.

6. Jacquez, J.A.; Biesele, J.J. A study of Michel's film on meiosis in Psophus stridulus L. Exp Cell Res. 1954, 6, 17-29. [CrossRef]

7. Bloom, K.S. Beyond the code: The mechanical properties of DNA as they relate to mitosis. Chromosoma 2008, 117, 103-110. [CrossRef]

8. Salmon, E.D.; Bloom, K. Tension sensors reveal how the kinetochore shares its load. BioEssays 2017, 39, 1600216. [CrossRef]

9. Reynolds, O. XXIX. An experimental investigation of the circumstances which determine whether the motion of water shall be direct or sinuous, and of the law of resistance in parallel channels. Philos. Trans. Royal Soc. London 1883, 174, 935-982.

10. Yan, L.; Chen, Z. A Unifying Mechanism of DNA translocation underlying chromatin remodeling. Trends Biochem Sci. 2019, 45, 217-227. [CrossRef]

11. Gosline, J.; Lillie, M.; Carrington, E.; Guerette, P.; Ortlepp, C.; Savage, K. Elastic proteins: Biological roles and mechanical properties. Philos. Trans. Royal Soc. B Biol. Sci. 2002, 357, 121-132. [CrossRef]

12. Denny, M. The physical properties of spider's silk and their tole in the design of orb-webs. J. Exp. Biol. 1976, 65, 483-506.

13. Ker, R.F. Dynamic tensile properties of the plantaris tendon of sheep (Ovis aries). J. Exp. Biol. 1981, 93, 283-302.

14. Urry, D.W.; Hugel, T.; Seitz, M.; Gaub, H.E.; Sheiba, L.; Dea, J.; Xu, J.; Parker, T. Elastin: A representative ideal protein elastomer. Philos. Trans. Royal Soc. B Biol. Sci. 2002, 357, 169-184. [CrossRef] [PubMed]

15. Melters, D.P.; Pitman, M.; Rakshit, T.; Dimitriadis, E.K.; Bui, M.; Papoian, G.A.; Dalal, Y. Intrinsic elasticity of nucleosomes is encoded by histone variants and calibrated by their binding partners. Proc. Natl. Acad. Sci. USA 2019, 116, 24066-24074. [CrossRef] [PubMed]

16. Chambers, R.; Sands, H.C. A dissection of the chromosomes in the pollen mother cells of Tradescantia virginica L. J. Gen. Physiol. 1923, 5, 815. [CrossRef] [PubMed]

17. D'Angelo, E.G. Micrurgical studies on Chironomus salivary gland chromosomes. Biol. Bull. 1946, 90, 71-87. [CrossRef]

18. D'Angelo, E.G. Salivary gland chromosomes. Ann. N. Y. Acad. Sci. 1950, 50, 910-919. [CrossRef]

19. Nicklas, R.B. A quantitative study of chromosomal elasticity and its influence on chromosome movement. Chromosoma 1963, 14, 276-295. [CrossRef]

20. Smith, S.B.; Cui, Y.; Bustamante, C. Overstretching B-DNA: The elastic response of individual double-stranded and single-stranded DNA molecules. Science 1996, 271, 795-799. [CrossRef]

21. García, A.E. Large-amplitude nonlinear motions in proteins. Phys. Rev. Lett. 1992, 68. [CrossRef]

22. Korostelev, A.; Noller, H.F. Analysis of structural dynamics in the ribosome by TLS crystallographic refinement. J. Mol. Biol. 2007, 373, 1058-1070. [CrossRef] [PubMed]

23. Radmacher, M.; Fritz, M.; Cleveland, J.P.; Walters, D.A.; Hansma, P.K. Imaging adhesion forces and elasticity of lysozyme adsorbed on mica with the atomic force microscope. Langmuir 1994, 10, 3809-3814. [CrossRef]

24. Vinckier, A.; Semenza, G. Measuring elasticity of biological materials by atomic force microscopy. FEBS Lett. 1998, 430, 12-16. [CrossRef]

25. Afrin, R.; Alam, M.T.; Ikai, A. Pretransition and progressive softening of bovine carbonic anhydrase, I.I. as probed by single molecule atomic force microscopy. Protein Sci. 2009, 14, 1447-1457. [CrossRef] [PubMed] 
26. Parra, A.; Casero, E.; Lorenzo, E.; Pariente, F.; Vázquez, L. Nanomechanical properties of globular proteins: Lactate oxidase. Langmuir 2007, 23, 2747-2754. [CrossRef] [PubMed]

27. Rakshit, T.; Banerjee, S.; Mishra, S.; Mukhopadhyay, R. Nanoscale mechano-electronic behavior of a metalloprotein as a variable of metal content. Langmuir 2013, 29, 12511-12519. [CrossRef]

28. Roos, W.H. AFM nanoindentation of protein shells, expanding the approach beyond viruses. In Seminars in Cell \& Developmental Biology; Academic Press: Cambridge, MA, USA, 2018.

29. Perrino, A.P.; Garcia, R. How soft is a single protein? the stress-strain curve of antibody pentamers with 5 pN and 50 pm resolutions. Nanoscale 2016, 8, 9151-9158. [CrossRef]

30. Marshall, W.F.; Marko, J.F.; Agard, D.A.; Sedat, J.W. Chromosome elasticity and mitotic polar ejection force measured in living Drosophila embryos by four-dimensional microscopy-based motion analysis. Curr. Biol. 2001, 11, 569-578. [CrossRef]

31. Nicklas, R.B. Measurements of the force produced by the mitotic spindle in anaphase. J. Cell Biol. 1983, 97, 542-548. [CrossRef]

32. De Vries, A.H.B.; Krenn, B.E.; Van Driel, R.; Subramaniam, V.; Kanger, J.S. Direct observation of nanomechanical properties of chromatin in living cells. Nano Lett. 2007, 7, 1424-1427. [CrossRef]

33. Na, S.; Collin, O.; Chowdhury, F.; Tay, B.; Ouyang, M.; Wang, Y.; Wang, N. Rapid signal transduction in living cells is a unique feature of mechanotransduction. Proc. Natl. Acad. Sci. USA 2008, 105, 6626-6631. [CrossRef] [PubMed]

34. Kirby, T.J.; Lammerding, J. Emerging views of the nucleus as a cellular mechanosensor. Nat. Cell Biol. 2018, 20, 373-381. [CrossRef] [PubMed]

35. Miroshnikova, Y.A.; Nava, M.M.; Wickström, S.A. Emerging roles of mechanical forces in chromatin regulation. J. Cell Sci. 2017, 130, 2243-2250. [CrossRef] [PubMed]

36. Maurer, M.; Lammerding, J. The driving force: Nuclear mechanotransduction in cellular function, fate, and disease. Annu. Rev. Biomed. Eng. 2019, 21, 443-468. [CrossRef] [PubMed]

37. Bustin, M.; Misteli, T. Nongenetic functions of the genome. Science 2016, 352. [CrossRef] [PubMed]

38. Tajik, A.; Zhang, Y.; Wei, F.; Sun, J.; Jia, Q.; Zhou, W.; Singh, R.; Knanna, N.; Belmont, A.S.; Wang, N. Transcription upregulation via force-induced direct stretching of chromatin. Nat. Mater. 2016, 15, 1287-1296. [CrossRef]

39. Levens, D.; Baranello, L.; Kouzine, F. Controlling gene expression by DNA mechanics: Emerging insights and challenges. Biophys. Rev. 2016, 8, 23-32. [CrossRef]

40. Poirier, M.G.; Marko, J.F. Micromechanical studies of mitotic chromosomes. Curr. Top Dev. Biol. 2003, 16, 469. [CrossRef]

41. Marko, J.F. Physics and biology (of chromosomes). J. Mol. Biol. 2019, 432, 621-623. [CrossRef]

42. Fierz, B.; Poirier, M.G. Biophysics of chromatin dynamics. Annu. Rev. Biophys. 2019, 48, 321-345. [CrossRef]

43. Spagnol, S.T.; Armiger, T.J.; Dahl, K.N. Mechanobiology of chromatin and the nuclear interior. Cell Mol. Bioeng. 2016, 9, 268-276. [CrossRef] [PubMed]

44. Starr, D.A. A nuclear-envelope bridge positions nuclei and moves chromosomes. J. Cell Sci. 2009, 122, 577-586. [CrossRef] [PubMed]

45. Bone, C.R.; Starr, D.A. Nuclear migration events throughout development. J. Cell Sci. 2016, 129, $1951-1961$. [CrossRef] [PubMed]

46. Xu, Z.; Maroney, A.C.; Dobrzanksi, P.; Kukekov, N.V.; Greene, L.A. The MLK Family mediates c-jun n-terminal kinase activation in neuronal apoptosis. Society 2001, 21, 4713-4724. [CrossRef]

47. Jahed, Z.; Hao, H.; Thakkar, B.; Vu, U.T.; Valdez, V.A.; Rathish, A.; Tolentino, C.; Kim, S.C.J.; Fadavi, D.; Starr, D.A.; et al. Role of KASH domain lengths in the regulation of LINC complexes. Mol. Biol. Cell 2019, 30, 2076-2086. [CrossRef]

48. Griffis, A.H.N.; Groves, N.; Groves, N.R.; Zhou, X.; Meier, I. Nuclei in motion: Movement and positioning of plant nuclei in development, signaling, symbiosis, and disease. Front. Plant Sci. 2014, 5. [CrossRef]

49. Wang, A.; Kohle, J.A.; Gioacchini, N.; Baade, I.; Brieher, W.M.; Peterson, C.L.; Freeman, B.C. Mechanism of long-range chromosome motion triggered by gene activation. Dev. Cell 2020, 52, 309-320. [CrossRef]

50. Schreiner, S.M.; Koo, P.K.; Zhao, Y.; Mochrie, S.G.J.; King, M.C. The tethering of chromatin to the nuclear envelope supports nuclear mechanics. Nat. Commun. 2015, 6, 1-13. [CrossRef] 
51. Earle, A.J.; Kirbu, T.K.; Fedorchak, G.R.; Isermann, P.; Patel, J.; Iruvanti, S.; Moore, S.A.; Bonne, G.; Wallrath, L.L.; Lammerding, J. Mutant lamins cause nuclear envelope rupture and DNA damage in skeletal muscle cells. Nat. Mater. 2019. [CrossRef]

52. Ziv, Y.; Bielopolski, D.; Lukas, C.; Taya, Y.; Schultz, D.C.; Lukas, J.; Bekker-Jensen, S.; Bartek, J.; Shiloh, Y. Chromatin relaxation in response to DNA double-strand breaks is modulated by a novel ATM-and KAP-1 dependent pathway. Nat. Cell Biol. 2006, 8, 870-876. [CrossRef]

53. Halicka, H.D.; Zhao, H.; Podhorecka, M.; Traganos, F.; Darzynkiewicz, Z. Cytometric detection of chromatin relaxation, an early reporter of DNA damage response. Cell Cycle 2009, 8, 2233-2237. [CrossRef] [PubMed]

54. Fortuny, A.; Polo, S.E. The response to DNA damage in heterochromatin domains. Chromosoma 2018, 127, 291-300. [CrossRef] [PubMed]

55. Estrem, C.; Moore, J.K. Astral microtubule forces alter nuclear organization and inhibit DNA repair in budding yeast. Mol. Biol. Cell 2019, 30, 2000-2013. [CrossRef] [PubMed]

56. Kidiyoor, G.R.; Kumar, A.; Foiani, M. ATR-mediated regulation of nuclear and cellular plasticity. DNA Repair 2016, 44, 143-150. [CrossRef]

57. Kumar, A.; Mazzanti, M.; Mistrik, M.; Kosar, M.; Beznoussenko, G.V.; Mironov, A.A.; Garrè, M.; Parazzoli, D.; Shivashankar, G.V.; Scita, G.; et al. ATR mediates a checkpoint at the nuclear envelope in response to mechanical stress. Cell 2014, 158, 633-646. [CrossRef] [PubMed]

58. Gay, S.; Foiani, M. Nuclear envelope and chromatin, lock and key of genome integrity. In International Review of Cell and Molecular Biology; Academic Press: Cambridge, MA, USA, 2015.

59. Burke, B. Chain reaction: LINC complexes and nuclear positioning. F1000 Res. 2019, 8. [CrossRef] [PubMed]

60. Hieda, M. Signal Transduction across the nuclear envelope: Role of the LINC complex in bidirectional signaling. Cells 2019, 8, 124. [CrossRef]

61. Le, H.Q.; Ghatak, S.; Yeung, C.Y.; Günschmann, C.; Dieterich, C.; Yeroslaviz, A.; Habermann, B.; Pombo, A.; Niessen, C.M.; Wickström, S.A. Mechanical regulation of transcription controls Polycomb-mediated gene silencing during lineage commitment. Nat. Cell Biol. 2016, 18, 864-875. [CrossRef]

62. Dekker, J.; Rippe, K.; Dekker, M.; Kleckner, N. Capturing chromosome conformation. Science 2002, 295, 1306-1311. [CrossRef]

63. de Wit, E.; de Laat, W. A decade of 3C technologies: Insights into nuclear organization. Genes. Dev. 2012, 26, 11-24. [CrossRef]

64. Sati, S.; Cavalli, G. Chromosome conformation capture technologies and their impact in understanding genome function. Chromosoma 2017, 126, 33-44. [CrossRef] [PubMed]

65. Lieberman-Aiden, E.; Van Berkum, N.L.; Williams, L.; Imakaev, M.; Ragoczy, T.; Telling, A.; Amit, I.; Lajoie, B.R.; Sabo, P.J.; Dorschner, M.O.; et al. Comprehensive mapping of long-range interactions reveals folding principles of the human genome. Science 2009, 326, 289-293. [CrossRef] [PubMed]

66. Boettiger, A.N.; Bintu, B.; Moffitt, J.R.; Wang, S.; Beliveau, B.J.; Fudenberg, G.; Imakaev, M.; Mirny, L.A.; $\mathrm{Wu}, \mathrm{C} . \mathrm{T}$; Zhuang, X. Super-resolution imaging reveals distinct chromatin folding for different epigenetic states. Nature 2016, 529, 418-422. [CrossRef] [PubMed]

67. Nir, G.; Farabella, I.; Pérez-Estrada, C.; Ebeling, C.G.; Beliveau, B.J.; Sasaki, H.M.; Lee, S.D.; Nguyen, S.C.; McCole, R.B.; Chattoraj, S.; et al. Walking along chromosomes with super-resolution imaging, contact maps, and integrative modeling. PLoS Genet. 2018, 14. [CrossRef]

68. McCord, R.P.; Kaplan, N.; Giorgetti, L. Chromosome conformation capture and beyond: Toward an integrative view of chromosome structure and function. Mol. Cell 2020, 77, 688-708. [CrossRef]

69. Rosa, A.; Di Stefano, M.; Micheletti, C. Topological constraints in eukaryotic genomes and how they can be exploited to improve spatial models of chromosomes. Front. Mol. Biosci. 2019, 6. [CrossRef]

70. Onuchic, J.N.; Wolynes, P.G. Theory of protein folding. Curr. Opin. Struct. Biol. 2004, 14, 70-75. [CrossRef]

71. Di Pierro, M.; Zhang, B.; Aiden, E.L.; Wolynes, P.G.; Onuchic, J.N. Transferable model for chromosome architecture. Proc. Natl. Acad. Sci. USA 2016, 113, 12168-12173. [CrossRef]

72. Haddad, N.; Vaillant, C.; Jost, D. IC-Finder: Inferring robustly the hierarchical organization of chromatin folding. Nucleic Acids Res. 2017, 45. [CrossRef]

73. Aumann, F.; Sühnel, J.; Langowski, J.; Diekmann, S. Rigid assembly and Monte Carlo models of stable and unstable chromatin structures: The effect of nucleosomal spacing. Theor. Chem. Acc. 2010, 125, $217-231$. [CrossRef] 
74. Ben-Haïm, E.; Lesne, A.; Victor, J.M. Chromatin: A tunable spring at work inside chromosomes. Phys. Rev. E 2001, 64. [CrossRef] [PubMed]

75. Schiessel, H.; Gelbart, W.M.; Bruinsma, R. DNA folding: Structural and mechanical properties of the two-angle model for chromatin. Biophys. J. 2001, 80, 1940-1956. [CrossRef]

76. Depken, M.; Schiessel, H. Nucleosome shape dictates chromatin fiber structure. Biophys. J. 2009, 96, 777-784. [CrossRef] [PubMed]

77. Wong, H.; Victor, J.M.; Mozziconacci, J. An all-atom model of the chromatin fiber containing linker histones reveals a versatile structure tuned by the nucleosomal repeat length. PLoS ONE 2007, 2. [CrossRef] [PubMed]

78. Koslover, E.F.; Fuller, C.J.; Straight, A.F.; Spakowitz, A.J. Local geometry and elasticity in compact chromatin structure. Biophys. J. 2010, 99, 3941-3950. [CrossRef]

79. Winogradoff, D.; Zhao, H.; Dalal, Y.; Papoian, G.A. Shearing of the CENP-A dimerization interface mediates plasticity in the octameric centromeric nucleosome. Sci. Rep. 2015, 5, 17038. [CrossRef]

80. Pitman, M.; Dalal, Y.; Papoian, G.A. Minimal cylinder analysis reveals the mechanical properties of oncogenic nucleosomes. Biophys. J. 2020. [CrossRef]

81. Lacoste, N.; Woolfe, A.; Tachiwana, H.; Garea, A.V.; Barth, T.; Cantaloube, S.; Kurumizaka, H.; Imhof, A.; Almouzni, G. Mislocalization of the centromeric histone variant CenH3/CENP-A in human cells depends on the chaperone DAXX. Mol. Cell 2014, 53, 631-644. [CrossRef]

82. Athwal, R.K.; Walkiewicz, M.P.; Baek, S.; Fu, S.; Biu, M.; Camps, J.; Ried, T.; Sung, M.H.; Dalal, Y. CENP-A nucleosomes localize to transcription factor hotspots and subtelomeric sites in human cancer cells. Epigenetics Chromatin 2015, 8, 2. [CrossRef]

83. Hergeth, S.P.; Schneider, R. The H1 linker histones: Multifunctional proteins beyond the nucleosomal core particle. EMBO Rep. 2015, 16, 1439-1453. [CrossRef]

84. Clausell, J.; Happel, N.; Hale, T.K.; Doenecke, D.; Beato, M. Histone H1 subtypes differentially modulate chromatin condensation without preventing ATP-dependent remodeling by SWI/SNF or NURF. PLoS ONE 2009, 4, e0007243. [CrossRef] [PubMed]

85. Perišić, O.; Portillo-Ledesma, S.; Schlick, T. Sensitive effect of linker histone binding mode and subtype on chromatin condensation. Nucleic Acids Res. 2019, 47, 4948-4957. [CrossRef] [PubMed]

86. Fenley, A.T.; Anandakrishnan, R.; Kidane, Y.H.; Onufriev, A.V. Modulation of nucleosomal DNA accessibility via charge-altering post-translational modifications in histone core. Epigenetics Chromatin 2018, 11. [CrossRef] [PubMed]

87. Bui, M.; Pitman, M.; Nuccio, A.; Roque, S.; Donlin-Asp, P.G.; Nita-Lazar, A.; Papoian, G.A.; Dalal, Y. Internal modifications in the CENP-A nucleosome modulate centromeric dynamics. Epigenetics Chromatin 2017, 10. [CrossRef] [PubMed]

88. Manohar, M.; Mooney, A.M.; North, J.A.; Nakkula, R.J.; Picking, J.W.; Edon, A.; Fishel, R.; Poirier, M.G.; Ottesen, J.J. Acetylation of histone $\mathrm{H} 3$ at the nucleosome dyad alters DNA-histone binding. J. Biol. Chem. 2009, 284, 23312-23321. [CrossRef] [PubMed]

89. Tropberger, P.; Pott, S.; Keller, C.; Kamieniarz-Gdula, K.; Caron, M.; Richter, F.; Li, G.; Mittler, G.; Liu, E.T.; Bühler, M.; et al. Regulation of transcription through acetylation of H3K122 on the lateral surface of the histone octamer. Cell 2013, 152, 859-872. [CrossRef]

90. Chatterjee, N.; North, J.A.; Dechassa, M.L.; Manohar, M.; Prasad, R.; Luger, K.; Ottesen, J.J.; Poirier, M.G.; Bartholomew, B. Histone Acetylation near the Nucleosome Dyad Axis Enhances Nucleosome Disassembly by RSC and SWI/SNF. Mol. Cell Biol. 2015, 35, 4083-4092. [CrossRef]

91. John, S.; Sabo, P.J.; Thurman, R.E.; Sung, M.-H.; Biddie, S.C.; Johnson, T.A.; Hager, G.L.; Stamatoyannopoulos, J.A. Chromatin accessibility pre-determines glucocorticoid receptor binding patterns. Nat. Genet. 2011, 43, 264. [CrossRef]

92. Simon, M.; North, J.A.; Shimko, J.C.; Forties, R.A.; Ferdinand, M.B.; Manohar, M.; Zhang, M.; Fishel, R.; Ottesen, J.J.; Poirier, M.G. Histone fold modifications control nucleosome unwrapping and disassembly. Proc. Natl. Acad. Sci. USA 2011, 108, 12711-12716. [CrossRef]

93. Lai, W.K.M.; Pugh, B.F. Understanding nucleosome dynamics and their links to gene expression and DNA replication. Nat. Rev. Mol. Cell Biol. 2017, 18, 548. [CrossRef]

94. Tauran, Y.; Kumermura, M.; Tarhan, M.C.; Perret, G.; Perret, F.; Jalabert, L.; Collard, D.; Fujita, H.; Coleman, A.W. Direct measurement of the mechanical properties of a chromatin analog and the epigenetic effects of para-sulphonato-calix[4]arene. Sci. Rep. 2019, 9, 1-12. [CrossRef] [PubMed] 
95. Takizawa, Y.; Ho, C.-H.; Tachiwana, H.; Matsunami, H.; Kobayashi, W.; Suzuki, M.; Arimura, Y.; Hori, T.; Fukagawa, T.; Ohi, M.D.; et al. Cryo-EM structures of centromeric tri-nucleosomes containing a central CENP-A nucleosome. Structure 2020, 28, 44-53. [CrossRef] [PubMed]

96. Sanulli, S.; Trnka, M.J.; Dharmarajan, V.; Tibble, R.W.; Pascal, B.D.; Burlingame, A.L.; Griffin, P.R.; Gross, J.D.; Narlikar, G.J. HP1 reshapes nucleosome core to promote phase separation of heterochromatin. Nature 2019, 575, 390-394. [CrossRef] [PubMed]

97. Chen, Z.; Gabizon, R.; Brown, A.I.; Lee, A.; Song, A.; Díaz-Celis, C.; Kaplan, C.D.; Koslover, E.F.; Yao, T.; Bustamante, C. High-resolution and high-accuracy topographic and transcriptional maps of the nucleosome barrier. Elife 2019, 8, e48281. [CrossRef] [PubMed]

98. Nagashima, R.; Hibino, K.; Ashwin, S.S.; Babokhov, M.; Fujishiro, S.; Imai, R.; Nozaki, T.; Tamura, S.; Tani, T.; Kimura, H.; et al. Single nucleosome imaging reveals loose genome chromatin networks via active RNA polymerase II. J. Cell Biol. 2019, 218, 1511-1530. [CrossRef]

99. Nozaki, T.; Imai, R.; Tanbo, M.; Nagashima, R.; Tamura, S.; Tani, T.; Joti, Y.; Tomita, M.; Hibino, K.; Kanemaki, M.T.; et al. Dynamic organization of chromatin domains revealed by super-resolution live-cell imaging. Mol. Cell 2017, 67, 282-293. [CrossRef] [PubMed]

100. Shelansky, R.; Boeger, H. Nucleosomal proofreading of activator-promoter interactions. Proc. Natl. Acad. Sci. USA 2020, 117, 2456-2461. [CrossRef]

101. Ingber, D.E. Mechanobiology and diseases of mechanotransduction. Ann. Med. 2003, 35, 564-577. [CrossRef]

102. Costa, K.D. Single-cell elastography: Probing for disease with the atomic force microscope. Dis. Markers 2004, 19, 139-154. [CrossRef]

103. Tubbs, A.; Nussenzweig, A. Endogenous DNA damage as a source of genomic instability in cancer. Cell 2017, 168, 644-656. [CrossRef]

104. Rustøen Braadland, P.; Urbanucci, A. Chromatin reprogramming as an adaptation mechanism in advanced prostate cancer. Endocr. Relat. Cancer 2019. [CrossRef]

105. Kadoch, C.; Williams, R.T.; Calarco, J.P.; Miller, E.L.; Weber, C.M.; Braun, S.M.; Pulice, J.L.; Chory, E.J.; Crabtree, G.R. Dynamics of BAF-Polycomb complex opposition on heterochromatin in normal and oncogenic states. Nat. Genet. 2017, 49. [CrossRef] [PubMed]

106. Nye, J.; Sturgill, D.; Athwal, R.; Dalal, Y. HJURP antagonizes CENP-A mislocalization driven by the H3.3 chaperones HIRA and DAXX. PLoS ONE 2018, 13, e0205948. [CrossRef] [PubMed]

107. Greenberg, R.S.; Long, H.K.; Swigut, T.; Wysocka, J. Single amino acid change underlies distinct roles of H2A.Z subtypes in human syndrome. Cell 2019, 178, 1421-1436. [CrossRef] [PubMed]

108. Chamberlin, H.M.; Jain, I.M.; Corchado-Sonera, M.; Kelley, L.H.; Sharanya, D.; Jama, A.; Pabla, R.; Dawes, A.T.; Gupta, B.P. Evolution of transcriptional repressors impacts caenorhabditis vulval development. Mol. Biol. Evol. 2020. [CrossRef]

109. Clapier, C.R.; Cairns, B.R. The biology of chromatin remodeling complexes. Annu. Rev. Biochem. 2009, 78, 273-304. [CrossRef]

110. Baldi, S.; Korber, P.; Becker, P.B. Beads on a string-Nucleosome array arrangements and folding of the chromatin fiber. Nat. Struct. Mol. Biol. 2020, 27, 109-118. [CrossRef]

111. Koschmann, C.; Nunez, F.J.; Mendez, F.; Brosnan-Cashman, J.A.; Meeker, A.K.; Lowenstein, P.R.; Castro, M.G. Mutated chromatin regulatory factors as tumor drivers in cancer. Cancer Res. 2017, 77, 227-233. [CrossRef]

112. Nacev, B.A.; Feng, L.; Bagert, J.D.; Lemiesz, A.E.; Gao, J.; Soshnev, A.A.; Kundra, R.; Schultz, N.; Muir, T.W.; Allis, C.D. The expanding landscape of 'oncohistone' mutations in human cancers. Nature 2019, 567, 473-478. [CrossRef]

113. Wan, Y.C.E.; Liu, J.; Chan, K.M. Histone H3 mutations in cancer. Curr. Pharmacol. Rep. 2018, 4, $292-300$. [CrossRef]

114. Wu, G.; Broniscer, A.; McEachron, T.A.; Lu, C.; Paugh, B.S.; Becksfort, J.; Qu, C.; Ding, L.; Huether, R.; Parker, M.; et al. Somatic histone $\mathrm{H} 3$ alterations in pediatric diffuse intrinsic pontine gliomas and non-brainstem glioblastomas. Nat. Genet. 2012, 44, 251. [CrossRef] [PubMed]

115. Buczkowicz, P.; Hoeman, C.; Rakopoulos, P.; Pajovic, S.; Letourneau, L.; Dzamba, M.; Morrison, A.; Lewis, P.; Bouffet, E.; Bartels, U.; et al. Genomic analysis of diffuse intrinsic pontine gliomas identifies three molecular subgroups and recurrent activating ACVR1 mutations. Nat. Genet. 2014, 46, 451-456. [CrossRef] [PubMed] 
116. Taylor, K.R.; Mackay, A.; Truffaux, N.; Butterfield, Y.; Morozova, O.; Philippe, C.; Castel, D.; Grasso, C.S.; Vinci, M.; Carvalho, D.; et al. Recurrent activating ACVR1 mutations in diffuse intrinsic pontine glioma. Nat. Genet. 2014, 46, 457. [CrossRef] [PubMed]

117. Lewis, P.W.; Müller, M.M.; Koletsky, M.S.; Cordero, F.; Lin, S.; Banaszynski, L.A.; Garcia, B.A.; Muir, T.W.; Becher, O.J.; Allis, C.D. Inhibition of PRC2 activity by a gain-of-function H3 mutation found in pediatric glioblastoma. Science 2013, 340, 857-861. [CrossRef] [PubMed]

118. Mohammad, F.; Weissmann, S.; Leblanc, B.; Pandey, D.P.; Højfeldt, J.W.; Comet, I.; Zheng, C.; Johansen, J.V.; Rapin, N.; Porse, B.T.; et al. EZH2 is a potential therapeutic target for H3K27M-mutant pediatric gliomas. Nat. Med. 2017, 23, 483. [CrossRef]

119. Sun, L.; Pierrakeas, L.; Li, T.; Luk, E. Thermosensitive nucleosome editing reveals the role of DNA sequence in targeted histone variant deposition. Cell Rep. 2020, 30, 257-268. [CrossRef]

(C) 2020 by the authors. Licensee MDPI, Basel, Switzerland. This article is an open access article distributed under the terms and conditions of the Creative Commons Attribution (CC BY) license (http://creativecommons.org/licenses/by/4.0/). 